\title{
Downtime in the Automotive Industry Production Process - Cause Analysis
}

\author{
DOI: 10.12776/QIP.V23I2.1259
}

Radosław Wolniak

Received: 02 June 2019

Accepted: 17 June 2019

Published: 31 July 2019

\begin{abstract}
Purpose: The article presents an analysis of the application of selected quality management methods and tools in order to identify factors affecting downtimes in the production line, illustrated with an example of the automotive industry.

Methodology/Approach: The paper contains an analysis of downtimes in the production process using selected methods and tools of quality management. The authors used a combination of tools and methods to carry out the analysis. In this concept, first, the 5WHY method and the Ishikawa diagram were used.

Findings: The research results presented in the paper suggest that better results can be achieved by using a set of quality tools instead of one particular tool. The authors found that using a wide range of quality tools can be useful to reduce downtimes on the production line.

Research limitation/implication: The major limitation of the paper is that is based on one case of an organisation from the automotive industry. In the future, it will be necessary to conduct studies in more organisations so as to find out if the same result can be achieved.

Originality/Value of paper: The article is concerned with the use of quality management methods and tools to analyse production line breakdowns. Until present, in subject literature, the causes of downtimes have been analysed without differentiating between planned and unplanned downitmes of the production line.
\end{abstract}

Category: Research paper

Keywords: quality tools; production line; downtime; quality management; quality improvement; quality methods 


\section{INTRODUCTION}

The problems connected with using quality management methods and tools in the automotive industry are described in many papers in international literature. Many authors suggest that a tool is simple, stand-alone application, whereas a technique tends to be a more comprehensively integrated approach to problem solving (Dale and McQuarter, 1998).

One of the main assumptions underlying a quality management system is improving the ability to define nonconformities, as well as to plan and carry out corrective and preventive actions. ISO/TS 16949 is a standard for QMS. This standard outlines the specific requirements for the application of ISO 9001:2015 in automotive production and relevant service part organizations (Lin et al., 2004). This standard recognizes the uniqueness of every automotive supplier's process, while providing critical tools to help your company better meet customer specific requirements (Bakhtiar, Mohammad and Kazemzadeh, 2010; Wolniak, 2014; Skotnicka-Zasadzień, Wolniak and Zasadzień, 2017; Thia et al., 2005).

The findings of other authors (Bunney and Dale, 1997) suggest that the use of tools and techniques is a vital component of any successful improvement of. production processes. By using quality management tools, an organization can investigate problems, identify solutions and implement them in its work practice. Quality management tools are classified generally into two groups: soft and hard (Evans and Lindsay, 1999; Wilkinson and Wilmott, 1995). In this paper we concentrate on production organizations and their use of hard tools. The technical system consists of a set of tools, while the hard part includes production and work process control techniques which ensure the correct functioning of such processes, including among others quality control tools (Silombela and Mutingi, 2018).

A significant number of those methods are called systems, because they constitute an integral and necessary element of cooperation between organisations in the customer-supplier relations, (Liker and Hoseus 2009; Bandyopadhyay, 2007; Delbridge and Barton, 2007; Liker and Meier, 2008; Sila, Ebrahimpour and Birkholz, 2006; Żuchowski and Łagowski, 2004; Imai, 2007; Nazrul, Kumar and Datta, 2012; Łuczak and Wolniak, 2015; Wolniak and Skotnicka-Zasadzień, 2014; Skotnicka-Zasadzień, 2013).

When we try to solve a particular problem in the industry, it is not enough to use one particular tool, as it cannot provide a sufficient amount of data to cope with the problem. Quality tools such as for example, seven quality tools are usually perceived as too simplistic and not suitable to solve problems in the automotive industry (Dale, 2003). The best way is to establish a set of tools which can be applied together, using a similar method. The use of a combination of quality tools and techniques provides the possibility to (Bamford and Greatbansk, 2005):

- highlight complex data in a simple, visually powerful way, 
- evaluate areas that cause most problems,

- specify areas to be prioritized,

- show relationships between variables,

- establish causes of failures,

- show the distribution of data,

- establish whether the process takes place in a state of statistical control and determine the effect of specific causes.

Automotive industry organisations use many tools to analyse and improve their processes. The research done by Hys indicates that automotive organisations operating in Poland use mainly (Hys, 2014; Zasadzień, 2017):

- classical seven "old" tools of quality management (Pareto analysis, histograms, correlation charts, Ishikawa diagram, sheet counting data) $40 \%$ of organisations,

- "new" tools of quality management (affinity diagram, interrelationship diagram, tree diagram, prioritisation matrix, matrix diagram, process decision program chart) $-12.3 \%$ of organisations,

- statistical process control $-21.5 \%$ of organisations,

- other tools $-7.69 \%$ of organisations.

The implementation of quality methods and tools is not successful in all cases. It may be a failure as well. In source literature, one can find mentions of unsuccessful implementation of quality tools. They are connected with the following problems (Putri and Yusouf, 2008):

- lack of confidence in potential benefits prevents some companies from trying to implement quality tools,

- problems in determining how to choose from a large number of existing tools in various organisations,

- problems in determining how to react to new developments in quality tools and programs,

- lack of ability to follow developments and apply tools that were applied successfully in other companies.

To achieve success in the quality tools implementation process, we should deal with those problems carefully.

The problem analysed in this paper is connected with production downtimes. Resources, as well as time in an automotive organisation, are scarce, so it is important to reduce the unwanted downtimes and interruptions in the production process. The most useful information for a production manager is related to the 
duration of downtime due to performance of maintenance tasks and other production problems (Knezevic, 1994; Hussan et al., 2014; Zennaro et al., 2018; Stal et al., 2012). Reducing downtimes to improve efficiency is a well-known concept used in many industries. Its effectiveness depends on a particular case and a set of methods used (Battini et al., 2015). According to TPM framework, most downtimes related to failures in industrial organisations can be controlled and reduced (Bokrantz et al., 2016). The article analyses the production line that produces semi-finished products for the manufacture of ready-made two-pipe shock absorbers for the rear of passenger cars. The production process starts with cutting the pipes that are the main element of the finished shock absorber. The cut tube is given a shaping treatment, such as widening the ends, in order to locate the shock absorber bottom in a proper way at the later stages of production, and narrowing it in order to give it a proper shape that allows the shock absorber to be finally fixed in the car.

The finished pipes are stored in the storage area located next to the body production line. The production of shock absorber bodies starts with the delivery of pipes and components from the warehouse. The finished components are stored in the area located next to the final assembly line of the shock absorber, where the components delivered from previous areas and the warehouse are stored. The finished shock absorbers go to the painting line, where they are covered with protective paint that does not allow corrosion. Painted shock absorbers go to the last line, where they are packed into cardboard boxes, and the necessary accessories needed to mount a shock absorber in the car are added.

\section{METHODOLOGY}

The article concerns the use of various quality management methods and tools for analysis of downtimes on the production line. In the discussed enterprise, until the present, the quality management processes have not been improved. The company documentation does not provide information on whether traditional or modern quality management tools have been used or what quality methods have been applied.

We collected data from the analysed company about the time of the production line availability. For this purpose, we used control sheets. All working days, additional work days and holidays were calculated from the data obtained. Formulas 1-3 were used for calculations. The next step was the use of quality management methods and tools. First, the 5 WHY method was applied, next analysis was performed using the Ishikawa diagram. Many quality management methods and tools can be used in the case of this type of analysis. We chose the two above mentioned ones on the basis of our pilot studies conducted in organisations from the Silesian automotive industry. We asked engineers about particular tools which were useful in this type of problems, and we chose the two most important ones. 
After the analysis, improvement actions were proposed. Until present, the individual stages of analysis have not been used in the analysed enterprise. We supposed they would allow for reducing the duration of production line downtimes.

\section{RESULTS}

The application of quality management tools and methods in the surveyed enterprise provides opportunities and a starting point for a wider application of quality management elements to improve production processes in other organisations as well as in various industries. The analysis and evaluation of the availability time were divided into planned and unplanned stoppages of the production line, and the total time of the production line availability was calculated. Studies carried out in this way provide a broader view of the problem.

\subsection{Total Time of the Production Line Availability}

The time of production line availability was calculated as follows: all working days and additional working days were calculated; next, holiday days were deducted, such as holiday leaves, production stoppage time in the summer and winter season (annual leaves of employees) and the time of stocktaking. Each full working day consists of three production shifts, lasting 8 hours. In the event of needed production at the customer's request or failure to comply with the production plan over the weekend, the company management may arrange additional working hours, which are multiples of full 8-hour work shifts.

In order to calculate the total working time, the following formula (1) was used:

$$
T_{C}-T_{W}=T_{D}
$$

where:

$T_{D}$ - Time of production line availability

$T_{C}$ - Total time during the considered period

$T_{W}-$ Time off days

The total time of the production line availability was calculated as follows (2):

$$
1,054,080(\mathrm{~min})-337,440(\mathrm{~min})=716,640(\mathrm{~min})
$$

The calculated time of 716,640 minutes consists of 1,493 production shifts, lasting 480 minutes of work. The exact distribution of the number of shifts and working days is shown in Tab. 1. 
Table 1 - Time of the Production Line Availability

\begin{tabular}{|c|c|c|}
\hline Production line availability (min) & Days & Sum of the production line work (min) \\
\hline 480 & 12 & 716,640 \\
\hline 960 & 13 & \\
\cline { 1 - 2 } 1,440 & 485 & \\
\hline
\end{tabular}

Next, the production line downtime was calculated. The first stage of the analysis involved identifying the main groups of downtimes in order to categorise data with similar features; the division enables focusing on the major causes of the most important problems (Tab. 2).

Table 2 - Main Groups of Production Line Downtimes

\begin{tabular}{|c|l|l|r|}
\hline No. & \multicolumn{1}{|c|}{ Group } & \multicolumn{1}{|c|}{ Description } & Downtime (min) \\
\hline 1 & Planned downtime & $\begin{array}{l}\text { Breakfast break, cleaning, top-down production } \\
\text { stoppage }\end{array}$ & 71,607 \\
\hline 2 & Unplanned downtime & $\begin{array}{l}\text { Unplanned production stoppage, for example, due } \\
\text { to lack of components }\end{array}$ & 14,199 \\
\hline 3 & Failure & $\begin{array}{l}\text { Extended unplanned machine breakdown due to } \\
\text { technical stoppage }\end{array}$ & 1,565 \\
\hline 4 & Micro failure & $\begin{array}{l}\text { Short production stoppage that does not require } \\
\text { calling for maintenance services }\end{array}$ & 81,019 \\
\hline 5 & Conversion & $\begin{array}{l}\text { Replacing the machine equipment and changing } \\
\text { the production parameters }\end{array}$ & \\
\hline
\end{tabular}

\section{Table 3 - Summary of Reasons for Planned Downtimes and Their Duration}

\begin{tabular}{|l|r|}
\hline The cause of the planned downtime & Downtime (min) \\
\hline Breakfast break for employees & 29,860 \\
\hline TPM production line & 14,930 \\
\hline Cleaning the production line & 14,930 \\
\hline Cleaning the welding machine's burner & 11,417 \\
\hline Staff training & 280 \\
\hline Meeting for employees & 190 \\
\hline
\end{tabular}

In the further part, the causes of downtimes in the studied area will be analysed. They are divided into particular groups and listed in Tab. 2. All planned downtimes of the production lines were analysed. It results from the applicable 
law, the work organisation and the rules in force in the enterprise. The causes of planned production line downtimes and their duration are presented in Tab. 3 .

Breakfast break for employees - according to the Labor Code, during each 8-hour shift, an employee is entitled to a minimum 15 minutes break. The management of the plant decided to increase the break time from 15 to 20 minutes due to the significant distance separating the production hall, the canteen and the employee locker rooms.

TPM (Total Productive Maintenance) production line - an action is resulting from the TPM philosophy. At the beginning of each shift, the machine operator must perform several necessary steps to reduce the number of failures and breakdowns in the plant.

Cleaning the production line - this is an action based on the philosophy of " $5 \mathrm{~S}$ ". At the end of each production shift, the operator is required to clear his workstation of waste or garbage produced, organise tools and prepare the necessary materials for the next shift.

Meeting for employees - the meeting is aimed at raising the employees' awareness of the company's condition, planned production, results in previous months and planned development. Meetings are held regularly, with an average frequency of every 2-4 months. Meetings must be organized for all employees, which is why they take place during the production shift.

Training for operators -training takes place each time when pieces of body or shock absorbers that would endanger the customer's safety will be produced. The training is aimed at raising the operators' awareness of potential defects in their areas of work, which is why the plant management agreed to stop production for up to 10 minutes for each training course.

Cleaning of welding torches - welding torches need to be cleaned to prevent the production of bodies with damper welds connecting the pipe to the shock absorbers' ear. The cleaning of the burner has been included in the operator's manual of the machine and is performed after every 100 pieces of the manufactured product.

All reasons for planned downtimes affect the quality of products or result from the organisation of work; therefore, they are impossible to eliminate.

The changeover time is the main factor causing a long-term downtime from the time point of view and the most common factor of problems. During the period under consideration, the production line changeover occurred 4,894 times with an average number of 3.2 changeovers per day. In this paper, we used the definition according to which changeover is the time between the manufacture of the last piece and the commencement of the serial production of another batch. For each changeover of the production line, the standard time with the existing technology is 15 minutes. The entire period of the planned changeover time is 
qualified as an over-standard changeover time, which means additional downtime.

The total time spent on retooling in the period under consideration recorded in the production reports by the foremen during each shift was 81,019 minutes.

The standard changeover time of the production line was calculated with the following equation (3):

$$
\begin{aligned}
& \text { Changeover time } x \text { the number of retoolings } \\
& =\text { the standard changeover time }
\end{aligned}
$$

$$
15(\min ) \times 4,894=73,410(\mathrm{~min})
$$

The standard changeover time of 73,410 minutes is the time planned to change the tools and settings for the production of subsequent products. Normative changeover time results from specific procedures - it is a factor impossible to eliminate. However, in the process of line retooling, unplanned problems may occur, called the over-standard changeover time, which is calculated with the following formula (4):

$$
\text { Total time - normative time over - standard changeover time }
$$

$$
81,019(\min )-73,410(\min )=7,609(\min )
$$

The calculations show that the over-standard changeover time was 7,609 minutes. Based on data gathered during the period under consideration, three major causes of long transition time were identified:

- Incorrect description of the setting parameters in production technology

- Damaged production tool

- Incorrect description of the tool number in production technology

For each of the factors mentioned above, a " 5 WHY" analysis will be carried out to determine the exact source of the problem (Fig.1). 


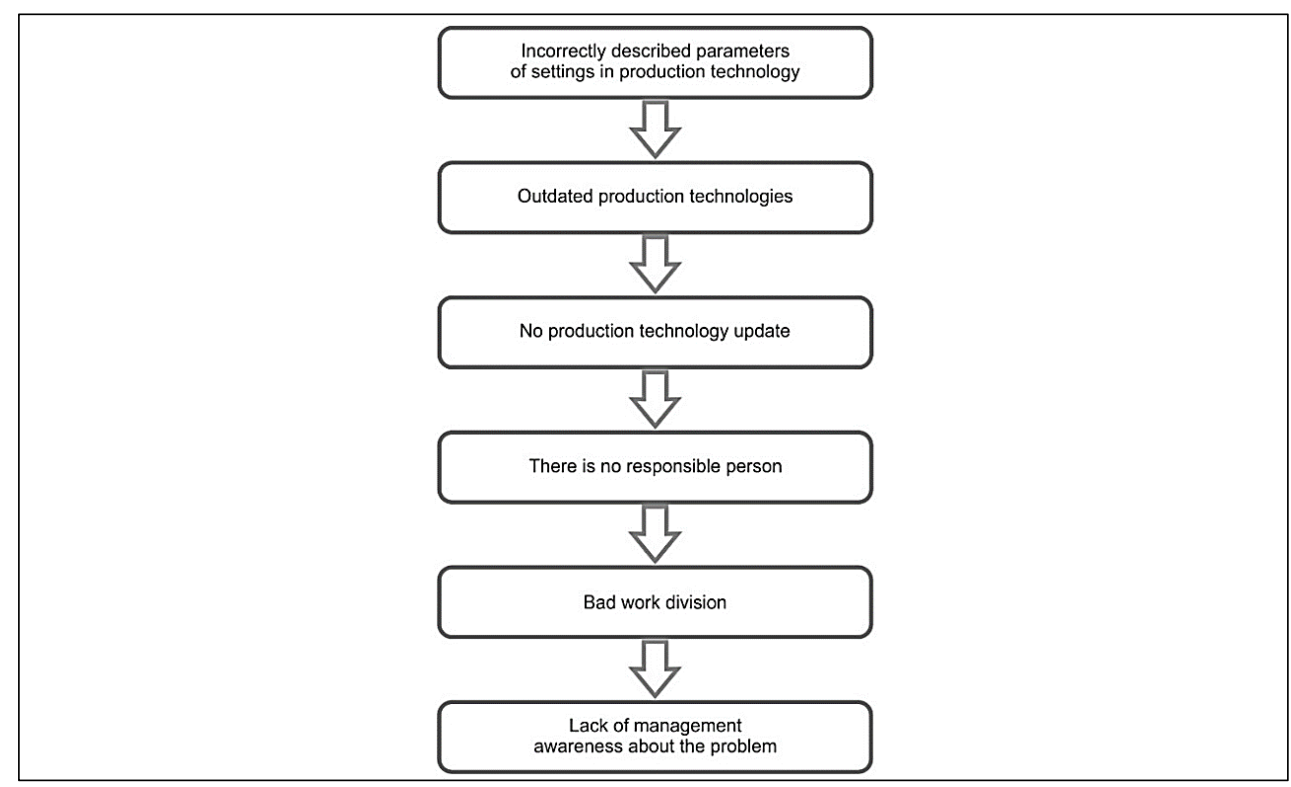

Figure 1-5 WHY Tools Used for Identifying the Causes of Incorrectly Described Technological Parameters of Production

We used 5 WHY tools to analyse the problem of erroneously described parameters of settings in the production technology. Based on our analysis, it was found that the major factor was lack of the management's awareness about the problem, resulting in failure to appoint a person responsible for systematic updates of the production technology.

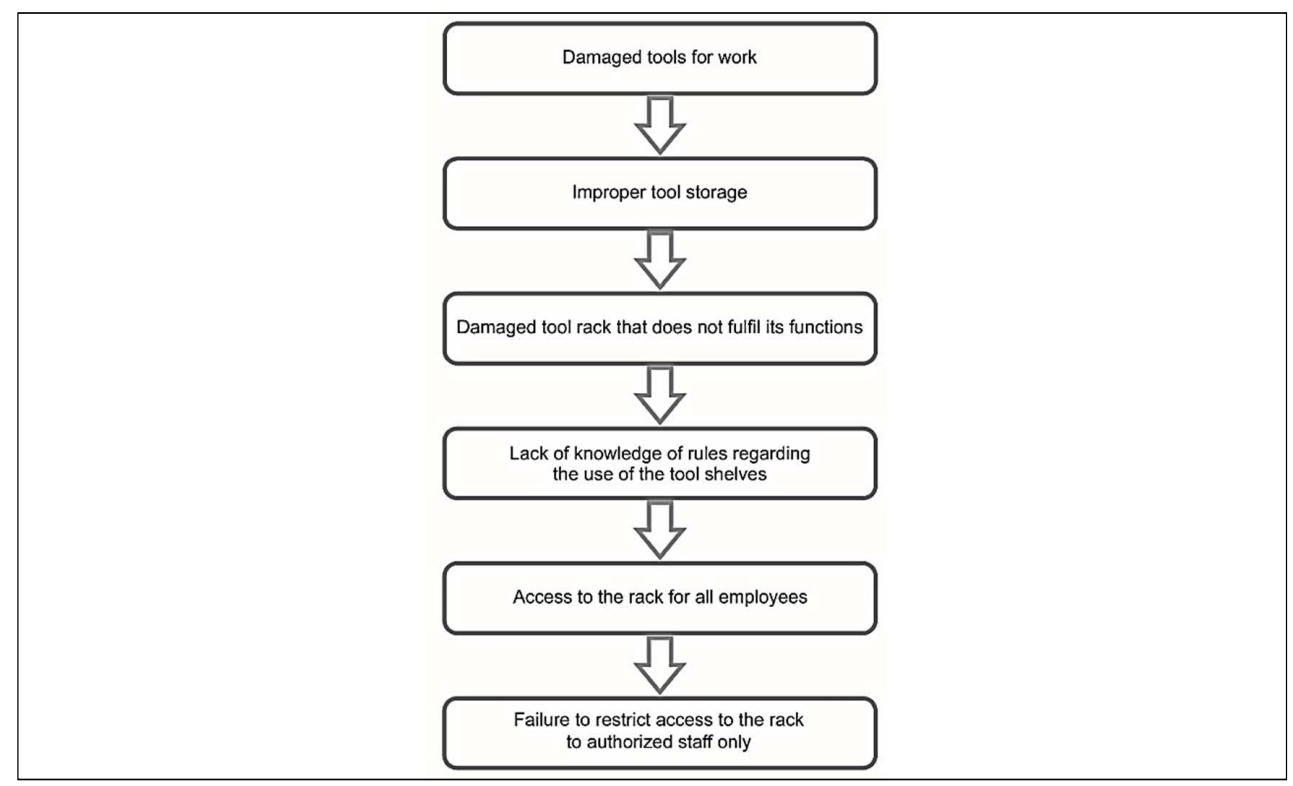

Figure 2 - 5 WHY Tools for Identifying the Cause of Damage to Production Tools 
We used 5 WHY tools to analyse the problem of damaged tools for production. Our analysis revealed that it resulted from failure to restrict access to the tool shelves to authorized staff only (Fig. 2).

We used 5 WHY tools to analyse the problem of erroneously described tool numbers in the production technology. We found that the main reason for that was the lack of management's awareness about the problem (Fig. 3).

Based on the conducted analysis, it was determined that the primary factor causing the over-normative changeover time was the lack of management's awareness of the problem and failure to restrict access to the toolbox only to authorised staff.

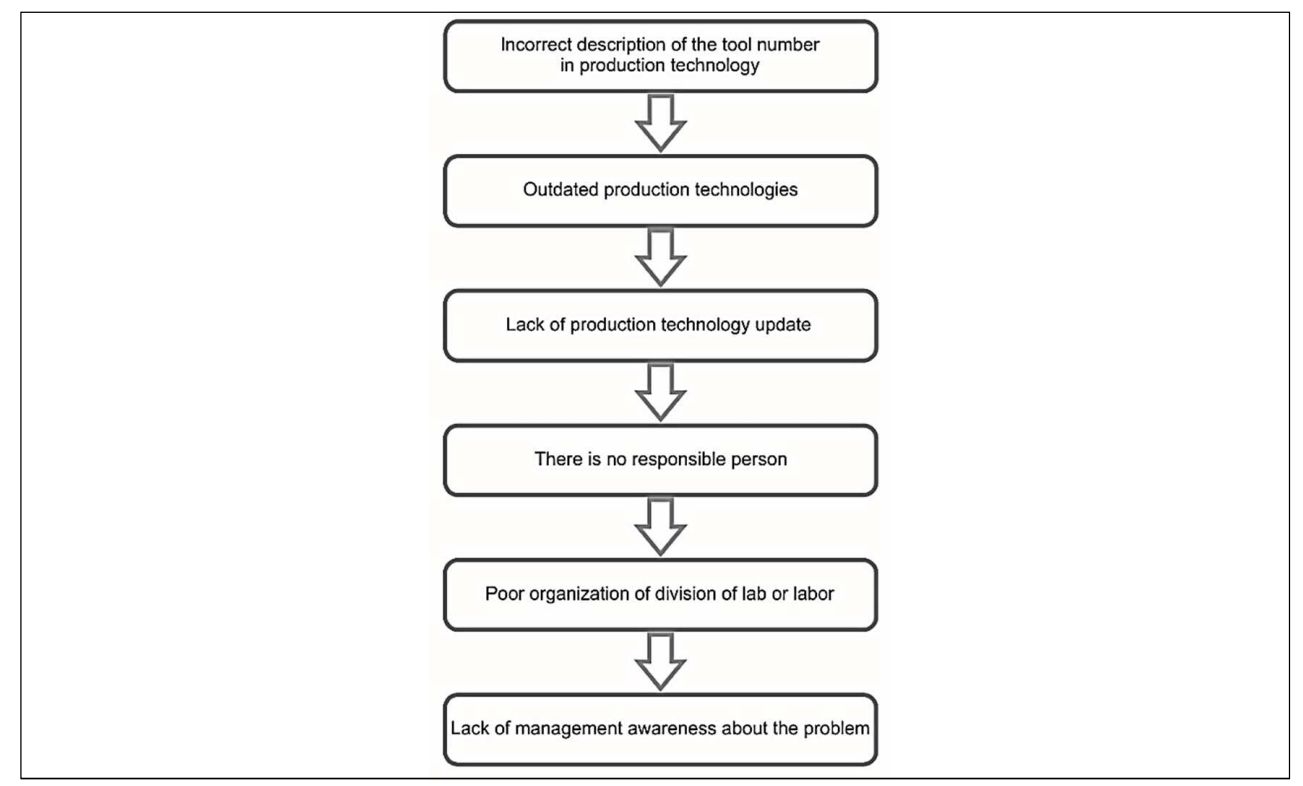

Figure 3 - 5 WHY Tools for Identifying the Cause of Incorrectly Described Tool Numbers in The Production Technology

\subsection{Unplanned Downtimes of the Production Line}

According to the data provided by the company, the total time of unplanned downtimes was 14,199 minutes. Particular causes of these downtimes are presented in Tab. 4. 
Table 4 - Summary of Reasons for Unplanned Downtimes

\begin{tabular}{|c|l|r|r|}
\hline No. & \multicolumn{1}{|c|}{ Causes of unplanned downtimes } & $\begin{array}{c}\text { Percentage share in all } \\
\text { unplanned downtimes }(\%)\end{array}$ & Downtime (min) \\
\hline 1 & Lack of pipes for production & 88.13 & 12,513 \\
\hline 2 & Pipes with defects unsuitable for production & 6.23 & 885 \\
\hline 3 & No comps from the warehouse & 5.64 & 801 \\
\hline
\end{tabular}

The use of a cause and effect diagram allowed us to analyse the causes of these downtimes (Fig. 4).

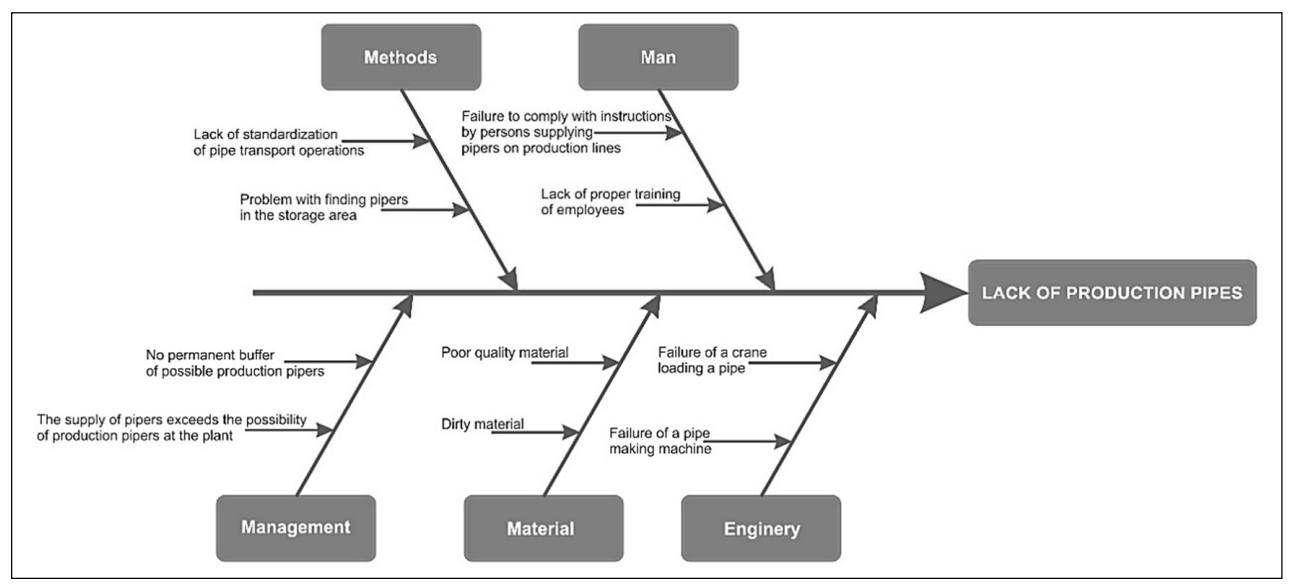

Figure 4 - Cause and Effect Analysis of Downtimes Due to Lack of Production Pipes

Failures of the production line. The production line downtime during the investigated period was 11,286 minutes. A list of all significant failures has been provided in Tab. 5.

Table 5 - Summary of Machine Failures Resulting in Downtimes

\begin{tabular}{|c|l|l|r|}
\hline No. & \multicolumn{1}{|c|}{ Machine } & \multicolumn{1}{|c|}{ The reason for the downtime } & Downtime (min) \\
\hline 1 & Welder & Failure of the welding electrode system & 4,120 \\
\hline 2 & Welder & Broken shaft & 1,656 \\
\hline 3 & Welder & Transformer failure & 970 \\
\hline 4 & Welder & Failure of the cooling system & 805 \\
\hline 5 & Welding apparatus & Failure of the welding curtain & 705 \\
\hline 6 & Welder & Power failure & 500 \\
\hline 7 & Welding apparatus & Tool failure & 420 \\
\hline
\end{tabular}




\begin{tabular}{|c|l|l|r|}
\hline No. & \multicolumn{1}{|c|}{ Machine } & \multicolumn{1}{|c|}{ The reason for the downtime } & Downtime (min) \\
\hline 8 & Welding apparatus & Torch burner failure & 330 \\
\hline 9 & Welder & Spring pusher failure & 310 \\
\hline 10 & Welder & Short circuits & 290 \\
\hline 11 & Water test & Failure of seals & 270 \\
\hline 12 & Welding apparatus & Power failure & 150 \\
\hline 13 & Welder & Broken fastening thread & 115 \\
\hline 14 & Welding apparatus & Broken pipe handle screw & 100 \\
\hline 15 & Welder & Control panel failure & 100 \\
\hline 16 & Welder & Start button failure & 95 \\
\hline 17 & Welding apparatus & Ventilation duct replacement & 80 \\
\hline 18 & Welding apparatus & Control panel failure & 70 \\
\hline 19 & Water test & Water leak & \\
\hline
\end{tabular}

The data contained in Tab. 6 shows that the welding machine is the one with the highest number of different types of failures.

Table 6 - List of Causes of Downtime as a Result of Machine Failures with a Cumulative Share

\begin{tabular}{|c|c|c|c|c|c|}
\hline No. & Cause of downtime & $\begin{array}{l}\text { Time } \\
(\min )\end{array}$ & $\begin{array}{c}\text { Percentage } \\
\text { share }(\%)\end{array}$ & $\begin{array}{c}\text { Cumulative share } \\
\text { of failures }(\%)\end{array}$ & Class \\
\hline 1 & Failure of the welding electrode system & 4,120 & 36.51 & 36.51 & A \\
\hline 2 & Broken cardan drive & 1,656 & 14.67 & 51.18 & A \\
\hline 3 & Transformer failure & 970 & 8.59 & 59.77 & A \\
\hline 4 & Transformer failure & 805 & 7.13 & 66.91 & A \\
\hline 5 & Failure of the welding curtain & 705 & 6.25 & 73.15 & A \\
\hline 6 & Power failure & 500 & 4.43 & 77.58 & A \\
\hline 7 & Tool failure & 420 & 3.72 & 81.30 & B \\
\hline 8 & Torch burner failure & 330 & 2.92 & 84.23 & B \\
\hline 9 & Spring pusher failure & 310 & 2.75 & 86.98 & B \\
\hline 10 & Short circuit & 290 & 2.57 & 89.54 & B \\
\hline 11 & Failure of seals & 270 & 2.39 & 91.94 & B \\
\hline 12 & Power supply & 200 & 1.77 & 93.71 & B \\
\hline
\end{tabular}




\begin{tabular}{|c|l|r|r|r|c|}
\hline No. & \multicolumn{1}{|c|}{ Cause of downtime } & $\begin{array}{r}\text { Time } \\
(\mathbf{m i n})\end{array}$ & $\begin{array}{c}\text { Percentage } \\
\text { share (\%) }\end{array}$ & $\begin{array}{c}\text { Cumulative share } \\
\text { of failures (\%) }\end{array}$ & Class \\
\hline 13 & Broken fastening thread & 150 & 1.33 & 95.04 & $\mathrm{C}$ \\
\hline 14 & Broken pipe handle screw & 115 & 1.02 & 96.06 & $\mathrm{C}$ \\
\hline 15 & Control panel failure & 100 & 0.89 & 96.94 & $\mathrm{C}$ \\
\hline 16 & Start button failure & 100 & 0.89 & 97.83 & $\mathrm{C}$ \\
\hline 17 & Ventilation duct replacement & 95 & 0.84 & 98.67 & $\mathrm{C}$ \\
\hline 18 & Control panel failure & 80 & 0.71 & 99.38 & $\mathrm{C}$ \\
\hline 19 & Water leak & 70 & 0.62 & 100.00 & $\mathrm{C}$ \\
\hline
\end{tabular}

The data presented in Tab. 6 shows the division of failures causing the machine downtime. A cause and effect analysis will be carried out for three failures causing the longest downtimes, to determine their exact causes (Fig. 5).

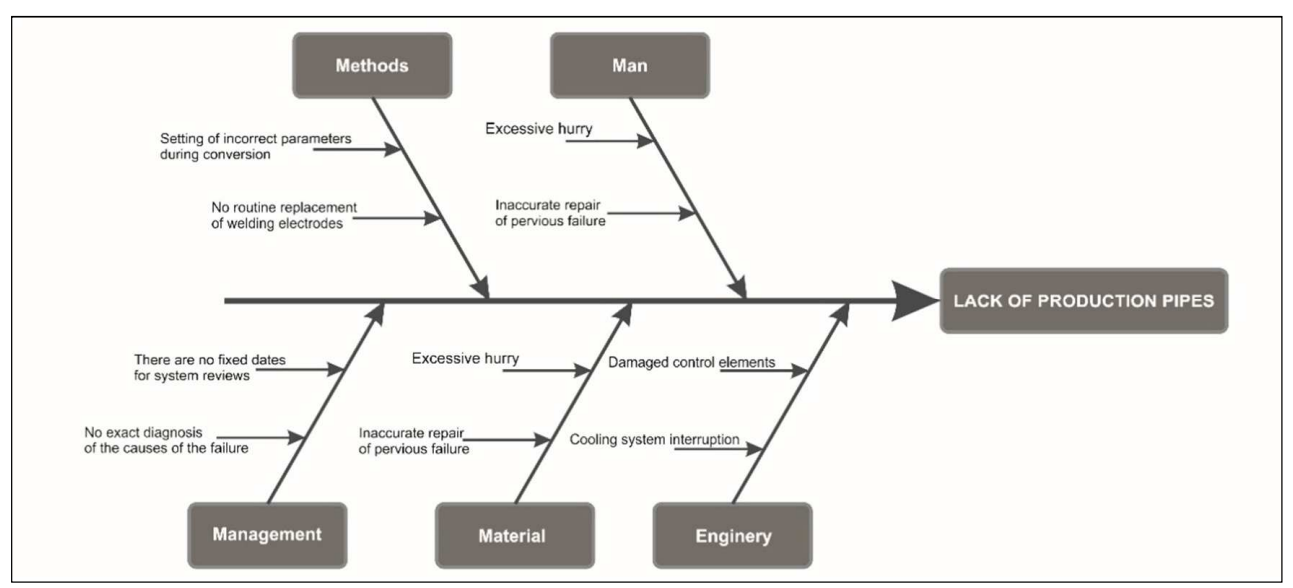

Figure 5 - Cause and Effect Analysis of Welding Electrode Failures

Micro-failures of the production line. During the period under consideration, the production line downtime due to micro-faults was 1,565 minutes. The list of all micro-faults is given in Tab. 7.

\section{Table 7 - List of Micro-Failure Causes with the Resulting Downtimes}

\begin{tabular}{|c|l|r|r|}
\hline No. & \multicolumn{1}{|c|}{ Cause of unplanned downtime } & $\begin{array}{c}\text { Percentage share in all } \\
\text { micro downtimes (\%) }\end{array}$ & Downtime (min) \\
\hline 1 & Problems with welding wire traction & 90.16 & 1420 \\
\hline 2 & Replacement of welding wire & 9.84 & 155 \\
\hline
\end{tabular}


The downtime resulting from welding wire traction failures was 1,420 minutes. It accounts for $90.16 \%$ of all the failures.

\section{DISCUSSION AND SUGGESTIONS FOR IMPROVEMENTS}

Based on conducted analyses and research, the following actions were proposed to reduce production line downtime: the main factors causing the over-standard time of line changeover were obsolete parameters and information about the manufacture of products in technological cards. Based on the problem analysis, it was found that the main reason for this was the failure to update the technological cards and conduct routine data checks due to problems with delegating a person responsible for the cause of the problem by the plant management.

The proposed improvements which should contribute to reducing the duration of downtimes include: appointing a person responsible for the correction of data in technological cards and c periodic reviews of data in the cards in order to obtain the effect of continuous control over the production process. The time intervals between successive failures of the welding system have been calculated. Also, preventive inspections and replacement of priority parts of machines related to this system have been proposed.

The failure of welding electrodes in the tested period occurred 135 times with a total downtime of 4,185 minutes. The average downtime was calculated using the equation (5):

$$
\operatorname{MTTR}=(4185 \mathrm{~min}) / 135
$$

The mean time to repair (MTTR) was 31 minutes. The next step was to calculate the time between the repair of failure and the time of its re-occurrence. The following calculations were made (6):

$$
\begin{gathered}
M T T F=(716,640 \mathrm{~min}-4,185 \mathrm{~min}) / 136 \\
M T B F=31 \mathrm{~min}+5,238 \mathrm{~min}
\end{gathered}
$$

The mean time between failures (MTBF) was 5,269 minutes, which translates into 87 hours and 49 minutes of machine operation.

This is the frequency with which inspections of welding electrodes should be conducted. This period ought to be adapted to the current work of an organisation. Therefore, maintenance service teams operating in the company should perform reviews during the breakfast break organised for employees of all 11 production shifts. Assuming that breakfast breaks take place during every shift, but in non-standard hours, usually between the $4^{\text {th }}$ and $6^{\text {th }}$ hour of work, 
inspections would usually take place after every 84-86 hours of machine operation. Another proposed improvement is to create instructions for correct installation of the welding wire in the welding machine and placing it in a place easily accessible to operators in order to verify their work during the replacement. The addition of welding wire position control in the welding chamber as a standard during each machine TPM inspection will depend on visual evaluation of the cleanliness inside the welding chamber.

\section{CONCLUSIONS}

The research results presented in the paper allow concluding that the application of a complex set of tools and quality management methods can give better results than using specific tools separately. The analysis allows concluding that: the failure of welding electrodes in the tested period occurred 135 times with a total downtime of 4,185 minutes. The average downtime (MTTR) was 31 minutes. The mean time to failure (MTTF) was 5,238 minutes, which translates into 87 hours and 18 minutes of machine operation. The mean time between failures (MTBF) was 5,269 minutes, which translates into 87 hours and 49 minutes of machine operation.

The use of individual tools may be insufficient when dealing with a complex production line or a specific type of industry, e.g. the automotive industry. Using a complex set of tools and quality management methods to solve a problem on the production line can in this situation bring more significant benefits and be more productive.

The research aimed to show that there is a great need to use specific sets of quality management tools and methods to improve production processes both in various industries and in enterprises diversified in terms of size. Both quantitative and quantitative methods should be used to analyse defects and errors in production processes.

Each company should depending on the needs and problems, establish its own set of tools and methods for quality management to improve the quality of the production processes, for example by reducing the production line downtime.

\section{ACKNOWLEDGEMENTS}

This paper was prepared with 13/010/BK_19/0034 - PROWIZORIUM.

\section{REFERENCES}

Bakhtiar, O., Mohammad, A. and Kazemzadeh, R.B., 2010. The impact of ISO/TS 16949 on automotive industries and created organizational capabilities from its implementation. Journal of Industrial Engineering and Management, [e-journal] 3(3), pp.494-511. http://dx.doi.org/10.3926/jiem.2010.v3n3. 
Bamford, D.R. and Greatbanks, R.W., 2005. The use of quality management tools and techniques: a study of application in everyday situations. International Journal of Quality \& Reliability Management, [e-journal 22(4), pp.376-392. http://dx.doi.org/10.1108/02656710510591219.

Bandyopadhyay, J.K., 2007. Six Sigma Approach of Quality Assurance in Global Supply Chains: A Study of United States Automakers. International Journal of Management, [online] Available at: $<$ https://www.questia.com/library/journal/1P3-1278577441/six-sigma-approachto-quality-assurance-in-global $>$ [Accessed 30 July 2019].

Battini, D., Persna, A., Sgarbosa, F., Zennaro, L. and Marchi, R., 2015. Downtime Analysis as a tool to improve efficiency in automated production lines. In: Summer School Francesco Turco, XX Summer School Francesco Turco - Industrial Systems Engineering. Naples, Italy, 16-18 September 2015. pp.162170.

Bokrantz, J., Skoogh, A., Ylipaa, T. and Stahre, J., 2016. Handling of production disturbances in the manufacturing industry. Journal of Manufacturing Technology Management, [e-journal] 27(8), pp.1054-1075. https://doi.org/10.1108/JMTM-02-2016-0023.

Bunney, H.S. and Dale, B.G., 1997. The implementation of quality management tools and techniques: a study. The TQM Magazine, [e-journal] 9(3), pp.183-189. https://doi.org/10.1108/09544789710168966.

Dale, B.G., 2003. Managing Quality. 4th ed.. Oxford: Blackwell Publishers.

Dale, B.G. and McQuater, R.E., 1998. Managing Business Improvement and Quality: Implementing Key Tools and Techniques. Oxford: Blackwell Publishers.

Delbridge, R. and Barton, H., 2007. Organizing for continuous improvement. Structures and roles in automotive components plants. International Journal of Operations \& Production Management, [e-journal] 22(6), pp.680-692. https://doi.org/10.1108/01443570210427686.

Evans, J.R. and Lindsay, W.M., 1999. The Management and Control of Quality. 4th ed.. Cincinnati: South-Western College Publishing.

Hussan, S.A., Lundberg, J., Wijaya, A. and Nehzad, G., 2014. Downtime analysis of drilling machines and suggestions for improvements. Journal of Quality in Maintenance Engineering, [e-journal] 20(4), pp.306-332. https://doi.org/10.1108/JQME-11-2012-0038.

Hys, K., 2014. Tools and methods used by the Polish leading automotive companies in quality management system. Results of empirical research. International Journal of Materials and Manufacturing, 63(1), pp.30-37.

Imai, M., 2007. KAIZEN. Kaizen: Kaizen Institute, MT Business Ltd.

Knezevic, J., 1994. Determination of Operations/Production Downtime for Group Replacement Maintenance Policy. International Journal of Operations \& 
Production Management, [e-journal] 14(7), pp.18-26. https://doi.org/10.1108/01443579410062130.

Liker, J.K. and Hoseus, M., 2009. Kultura Toyoty. Warszawa: MT Biznes Ltd..

Liker, J.K. and Meier, D.P., 2008. Toyota talent. Warszawa: MT Biznes Ltd..

Lin, W.T., Liu, C.H., Hsu, IC. and Lai, C.T., 2004. An Empirical Study of QS 9000 in the Automobile and Related Industries in Taiwan. Total Quality Management and Business Excellence, [e-journal] 15(3), pp.355-378. https://doi.org/10.1080/1478336042000183424.

Łuczak, J. and Wolniak, R., 2015. Problem-solving and developing quality management methods and techniques on the example of automotive industry. Manager Journal, 22(1), pp.237-250.

Nazrul, J.I., Kumar, H.M. and Datta, R., 2012. A Study on Job Satisfaction and Morale of Commercial Banks in Bangladesh. International Journal of Economics and research, 4(Jul-Aug), pp.153-173.

Putri, N.T. and Yusof, S.M., 2008. A Review of Quality Engineering Tools and Techniques Practices in Malaysia's and Indonesia's Automotive Industries and an Agenda for Future Rese. ICMIT, 4th IEEE International Conference Management of Innovation and Technology. Bangkok, Thailand, 21-24 September 2008. IEEE. https://doi.org/10.1109/ICMIT.2008.4654407.

Sila, I., Ebrahimpour, M. and Birkholz, Ch., 2006. Quality in supply chains: an empirical analysis. Supply Chain Management, [e-journal] 11(6), pp.491-502. https://doi.org/10.1108/13598540610703882.

Silombela, T. and Mutingi, M., 2018. Impact of quality management tools and techniques: Case of Namibian municipal water distributors. Journal of Quality in Maintenance Engineering, 24(1), pp.2-21.

Skotnicka-Zasadzień, B., 2013. Application of quality engineering elements for the improvement of production processes - case study. ICIEMS, International Conference on Industrial Engineering and Management Science. Shanghai, China, 28-29 September 2013. ICIEMS. pp.362-368.

Skotnicka-Zasadzień, B., Wolniak, R. and Zasadzień, M., 2017. Use of quality engineering tools and methods for the analysis of production processes - case study. FEBM, Proceedings of the Second International Conference on Economic and Business Management. Shanghai, China, 21-23 October 2017. Piman Limpaphayom, Gordon Huang: Atlantis Press. pp.240-245.

Stal, Ch., Gabrielson, P., Andersson, C. and Stahl, J.E., 2012. A production performance analysis regarding downtime and downtime pattern. FAIM, 22nd International Conference on Flexible Automation and Intelligent Manufacturing. 2012, Helsinki, Finland, 17 October 2011. Helsinki: Lund University. 
Thia, C.W., Chai, K.H., Bauly, J. and Xin, Y., 2005. An exploratory study of the use of quality tools and techniques in product development. The TQM Magazine, [e-journal] 17(5), pp.406-424. https://doi.org/10.1108/09544780510615924.

Wilkinson, A. and Willmott, H. eds., 1995. Making quality critical: new perspectives on organizational change, London, United Kingdom: Routledge.

Wolniak, R., 2014. Relationship between selected lean management tools and innovations. Zeszyty Naukowe, 75, pp.157-266.

Wolniak, R. and Skotnicka-Zasadzień, B., 2014. The use of value stream mapping to introduction of organizational innovation in industry. Metalurgija, 53(4), pp.709-712.

Zasadzień, M., 2017. Application of the Six Sigma method for improving maintenance processes - case study. ICORES, 6th International Conference on Operations Research and Enterprise Systems. Porto, Portugal, 23-25 February 2017. Setúbal: Science and Technology Publications.

Zennaro, I., Batiini, D., Sgarbossa, F., Persona, A. and Marchi, R., 2018. Micro downtime: Data collection, analysis and impact on OEE in bottling lines the San Benedetto case study. International Journal of Quality \& Reliability Management, 34(4), pp.965-995.

Żuchowski, J. and Łagowski, E., 2004. Narzędzia i metody doskonalenia jakości. Radom: Politechnika Radomska.

\section{ABOUT AUTHOR}

Radosław Wolniak - Silesian Technical University, Organization and Managemnt Faculty, Poland. E-mail: radek_wol@o2.pl, Author's ORCID: http://orcid.org/0000-0003-0317-9811.

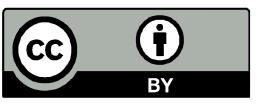

(C) 2019 by the authors. Submitted for possible open access publication under the terms and conditions of the Creative Commons Attribution (CC-BY) license (http://creativecommons.org/licenses/by/4.0/). 